Review

\title{
Characteristics of surfactant proteins in tumorigenic and inflammatory lung lesions in rodents
}

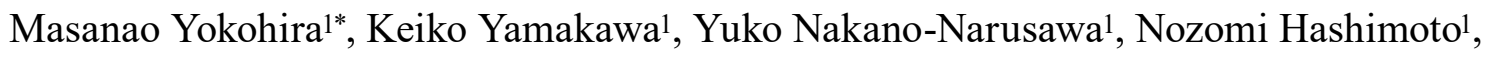 \\ Shohei Kanie', Shota Yoshida1, and Katsumi Imaida ${ }^{*}$ \\ ${ }^{1}$ Onco-Pathology, Faculty of Medicine, Kagawa University, 1750-1 Ikenobe, Miki-cho, Kita-gun, Kagawa 761-0793, Japan
}

\begin{abstract}
Surfactant proteins (SPs) are essential for the proper structure and respiratory function of the lungs. There are four subtypes of SPs: SP-A, SP-B, SP-C, and SP-D. The expectorant drug ambroxol hydrochloride is clinically used to stimulate pulmonary surfactant and airway serous secretion. In addition, previous studies showed that ambroxol regulated SP production and attenuated pulmonary inflammation, with ambroxol hydrochloride being found to suppress quartz-induced lung inflammation via stimulation of pulmonary surfactant and airway serous secretion. In this study, we investigated the expression of SP-A, SP-B, SP-C, and SP-D in neoplastic and inflammatory lung lesions in rodents, as well as their possible application as potential markers for diagnostic purposes. SP-B and SP-C showed strong expression in lung hyperplasia and adenoma, whereas SP-A and SP-D were expressed in the mucus or exudates of inflammatory alveoli. Rodent tumorigenic hyperplasic tissues induced by various carcinogens were positive for napsin A, an aspartic proteinase involved in the maturation of SP-B; this indicated a focal increase in type II pneumocytes in the lungs. Therefore, high expression of napsin A in the alveolar walls may serve as a useful marker for prediction of the tumorigenic potential of lung hyperplasia in rodents. (DOI: 10.1293/tox.2018-0025; J Toxicol Pathol 2018; 31: 231-240)
\end{abstract}

Key words: lungs, surfactant protein, napsin A, ambroxol hydrochloride, hyperplasia

\section{Introduction}

Surfactant proteins (SPs), originally known as human lung surfactants, are essential for the proper structure and respiratory function of the lungs. They are unique in composition, consisting of approximately $90 \%$ lipids, mostly phospholipids, and $8-10 \%$ surfactant-associated proteins 1 . SPs line the alveolar surface and reduce surface tension at the air-fluid interface ${ }^{2}$. They are stored mainly in type II alveolar epithelial cells in the form of densely packed bilayers, namely lamellar bodies, which are secreted and efficiently transferred to the interfacel, 2. There are four subtypes of SPs: SP-A, SP-B, SP-C, and SP-D. Of these subtypes, SP-A and SP-D probably play more important roles in host defense mechanisms, whereas SP-B and SP-C are crucial for lowering of surface tension in the lungs ${ }^{3}, 4$. SP-A, SP-B, and SP-D are synthesized in alveolar type II epithelial cells and Clara

Received: 20 April 2018, Accepted: 8 May 2018

Published online in J-STAGE: 2 June 2018

*Corresponding authors: M Yokohira

(e-mail: yokohira@med.kagawa-u.ac.jp)

K Imaida (e-mail: imaida@med.kagawa-u.ac.jp)

(C2018 The Japanese Society of Toxicologic Pathology

This is an open-access article distributed under the terms of the Creative Commons Attribution Non-Commercial No Derivatives (c) 1 BY NC cells, whereas SP-C expression is restricted to type II cells4. The expectorant drug ambroxol hydrochloride is clinically used to stimulate pulmonary surfactant and airway serous secretion, enhance airway ciliary movement, and facilitate the removal of sputum 5,6 . Previous studies showed that ambroxol regulated SP production and attenuated pulmonary inflammation. However, studies on the expression of SP-A, SP-B, SP-C, and SP-D in lung tumors are lacking.

In this study, we reviewed the functions of SPs and investigated the expression of SP-A, SP-B, SP-C, and SP-D in neoplastic and inflammatory lung lesions in rodents, as well as their possible application as potential markers for diagnostic purposes.

\section{The Role of Pulmonary SPs}

Many studies have showed the role of SPs in lung inflammation and chronic obstructive pulmonary disease (COPD). Pulmonary surfactants constitute a lipoprotein complex that lines the alveolar surface. Its main function is to reduce alveolar surface tension ${ }^{7}$. In addition, it acts as a modulator of immune responses. The two principal surfactant components involved in innate immunity in the alveoli are SP-A and SP-D ${ }^{8}$. SP-A/interferon (IFN) $-\gamma$ interaction plays a significant role in maintaining the immune balance to protect the alveolar epithelium 9 .

We investigated the modulatory effects of ambroxol hy- 
drochloride in quartz-induced lung inflammation in F344 rats. Animals were maintained at the Division of Animal Experiments, Life Science Research Center, Kagawa University. All animal experiments were carried out in accordance with the Institutional Regulations for Animal Experiments, which assure the best considerations on animal welfare and good practice of animal handling regarding the replacement, refinement, and reduction of animal testing (3Rs). The experimental protocol was approved by the Animal Care and Use Committee of Kagawa University. A previous study showed that iv administration of two doses (20 $\mathrm{mg} / \mathrm{kg}$ each) of the expectorant drug ambroxol hydrochloride with a 6-hour interval stimulated the synthesis and secretion of exogenous pulmonary surfactant in the lungs and protected Sprague Dawley (SD) rats against Pseudomonas aeruginosa pneumonia ${ }^{10}$. In addition, administration of ambroxol for 28 consecutive days at $35 \mathrm{mg} / \mathrm{kg}$ reduced paraquat-induced lung damage ${ }^{11}$.

Lung toxicity of fine particles of various materials was previously studied in an in vivo bioassay by using an intratracheal instillation (IT) approach ${ }^{12-14}$. In humans, construction workers, who had been exposed to quartz dust, exhibited obstructive and restrictive loss of lung capacity ${ }^{15}$, as well as COPD ${ }^{16,17}$. IT of quartz into rats resulted in inflammatory reactions followed by histological changes characteristic of lung fibrosis ${ }^{18}$, similar to the pathological changes observed in humans. IT of fine particles of quartz at a dose of $2 \mathrm{mg} / \mathrm{rat}$ induced severe inflammatory changes in the lungs characterized by neutrophil infiltration and edema after 28 days $^{13}$.

Male 6-week-old F344 rats were exposed to $2 \mathrm{mg}$ quartz particles suspended in $0.2 \mathrm{ml}$ of saline via IT instillation. Ambroxol hydrochloride (CAS 23828-92-4) was administered at 0,12 , and $120 \mathrm{ppm}$ in rat basal diet for 28 days. The mean ambroxol intake in each group was $12 \mathrm{ppm}$ $(0.91 \mathrm{mg} / \mathrm{kg} / \mathrm{day})$, which is proportionally comparable to the conventional dose in human subjects $(45 \mathrm{mg} /$ day, assuming a mean human body weight of $50 \mathrm{~kg}$ ). Inflammation scores of the lungs in this experiment are summarized in Table 1. Inflammation scores of pulmonary edema and lymph follicle proliferation around the bronchiole, as well as the total

Table 1. Inflammation Scores in the Lungs

\begin{tabular}{lcccc}
\hline \multirow{2}{*}{ Group } & \multicolumn{2}{c}{ Treatment } & & \\
\cline { 2 - 4 } & Quartz & $\begin{array}{c}\text { Ambroxol } \\
(\mathrm{ppm})\end{array}$ & No. of rats & Total score \\
& & 0 & 5 & \\
\hline 1 & - & 0 & 5 & $0.6 \pm 0.9$ \\
2 & + & 12 & 5 & $13.2 \pm 2.5$ \\
3 & + & 5 & $6.8 \pm 3.8$ \\
4 & + & 120 & 5 \\
\hline
\end{tabular}

aTotal score represent the summation of the points $(0$, no change; 1 , weak; 2, moderate; and 3, severe) of seven parameters for inflammatory findings, neutrophil infiltration in the alveolar wall or spaces, histiocytic macrophage infiltration in the alveoli, pulmonary edema, pulmonary fibrosis granuloma, and lymph follicle proliferation around the bronchiole. bSignificant difference vs. group 2 (Steel test, $P<0.05)$ scores, were significantly lower in quartz-exposed rats that received $120 \mathrm{ppm}$ ambroxol hydrochloride than in untreated quartz-exposed animals (Fig. 1).

In this study, ambroxol at a supra-clinical dose significantly reduced IT quartz-induced inflammation. At this dose level, there was no concern about ambroxol toxicity. Immunohistochemical analysis showed that the expression of inducible nitric oxide synthase (iNOS) and heme oxygenase-1 (HO-1) increased in the lungs following quartz IT instillation 1920 . In addition, an in vitro study showed that exposure of NR8383 macrophages to quartz induced reactive oxygen species (ROS), interleukin-1 beta (IL-1 $\beta$ ), and tumor necrosis factor alpha (TNF- $\alpha$ ) release ${ }^{20}$. Thus, quartzinduced lung inflammation was most probably attributed to both oxidative stress and the proinflammatory signaling pathway involving nuclear factor kappa-B $(\mathrm{NF}-\kappa \mathrm{B})^{21}$. Inhibition of quartz-induced release of ROS, reactive nitrogen species, and inflammatory mediators is expected to exert anti-inflammatory effects. Ambroxol administration has been shown to suppress lipopolysaccharide-induced production of TNF- $\alpha$, IL-1 $\beta$, interleukin-6 (IL-6), superoxide radical, hydrogen peroxide, and nitric oxide from rat macrophages in vitro 22 . In paraquat-induced lung fibrosis in rats, the protective effects of ambroxol were histologically prominent and presumably mediated by its free radical-scavenging and antioxidant activity ${ }^{11}$. Similar findings were obtained after ambroxol treatment in quartz-induced lung inflammation in rats. The anti-inflammatory effects of ambroxol might be also associated with the reduction of oxidative stress and inhibition of inflammatory cytokine production. It has been shown that ambroxol could reduce the adhesion of viscous sputum and enhance the movement of the cilia in the leporine trachea and tracheal mucosa exposed to sulfur dioxide $^{23}$. Recently, ambroxol hydrochloride was shown to suppress quartz-induced lung inflammation ${ }^{24}$.

\section{Characteristics of SP-A, SP-B, SP-C, and SP-D}

Four specific SPs have been designated as SP-A ${ }^{25}$, SPB, SP-C, and SP-D. They are produced by alveolar type II cells and Clara cells. SP-B and SP-C are hydrophobic proteins, which are essential for surface tension reduction ${ }^{26}$. SP-A and SP-D are hydrophilic proteins that belong to the C-type lectin superfamily ${ }^{26}$. Studies on the expression of SP-A, SP-B, SP-C, and SP-D in lung tumors are rare. We examined and compared the expression of SP-A, SP-B, SP$\mathrm{C}$, and SP-D in rat neoplastic lung lesions induced by $0.1 \%$ $\mathrm{N}-$ Nitrosodiisopropanolamine (DHPN) ${ }^{27}$ and in rat inflammatory lung lesions induced by IT exposure to quartz particles using immunohistochemical analyses ${ }^{12-14}$.

The lungs of the rats exposed to quartz showed inflammatory lesions after 28 days (Fig. 2A) compared with the control group. The main findings were neutrophil infiltration in the walls and spaces of the alveoli, pulmonary edema, pulmonary fibrosis, alveolar macrophage infiltration, restructuring of the alveolar walls, and granulation-like changes with giant cells and macrophages in the alveoli. 

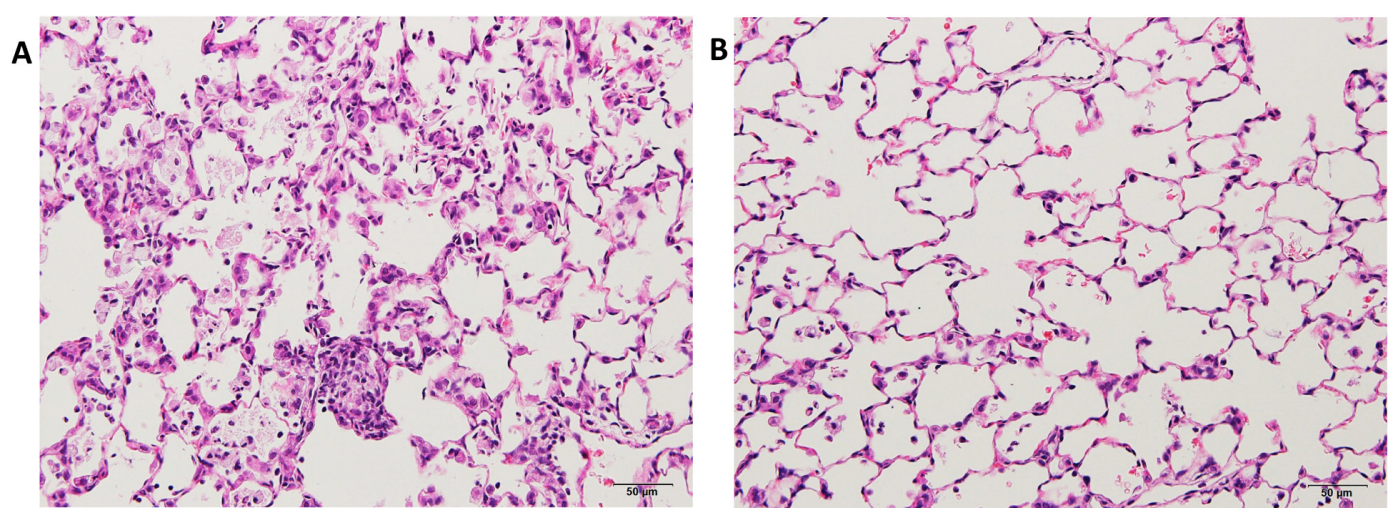

Fig. 1. Histopathological findings in quartz-induced inflammatory lesions in F344 rat lungs (H \& E). A, lungs treated with 0 ppm ambroxol hydrochloride; and B, lung treated with $120 \mathrm{ppm}$ ambroxol hydrochloride. The figure shows neutrophil and histiocytic macrophage infiltration (A), whereas treatment with $120 \mathrm{ppm}$ ambroxol hydrochloride decreased all these inflammatory signs (B).

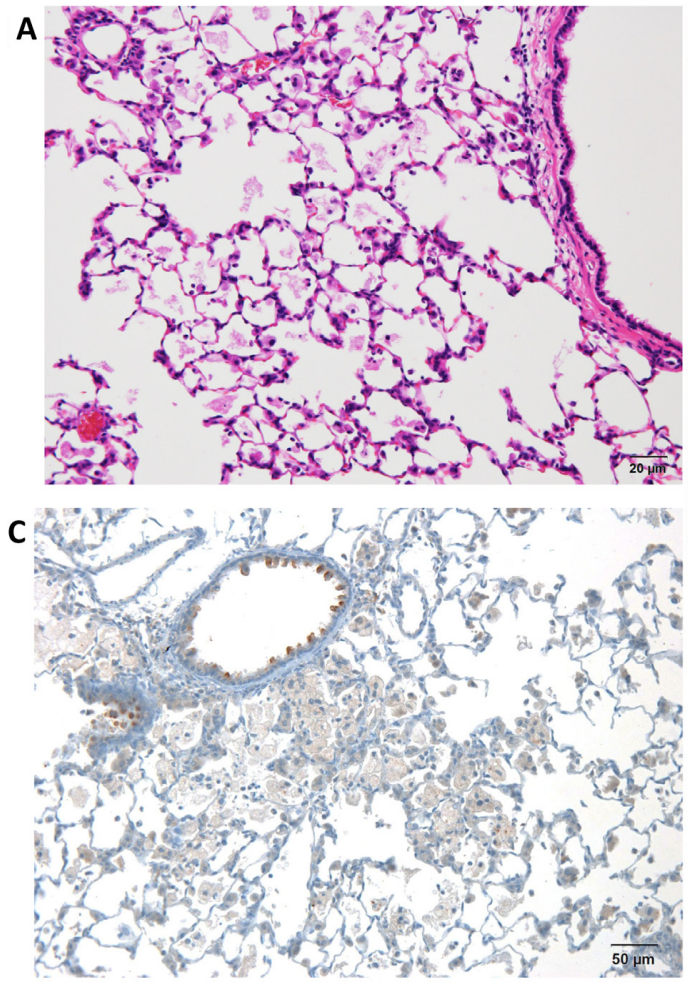

E

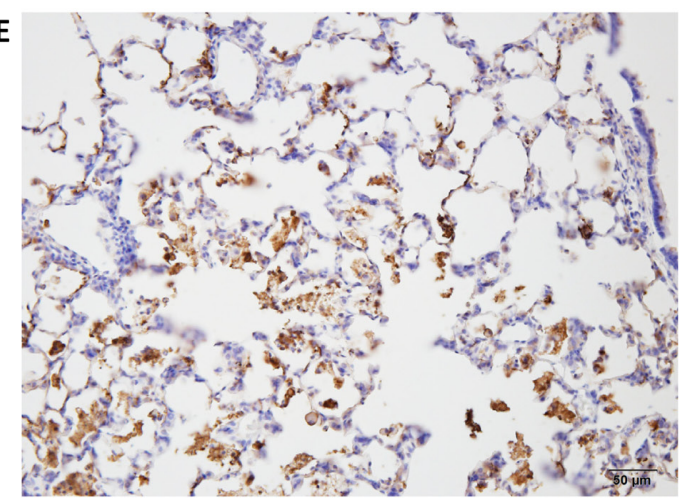

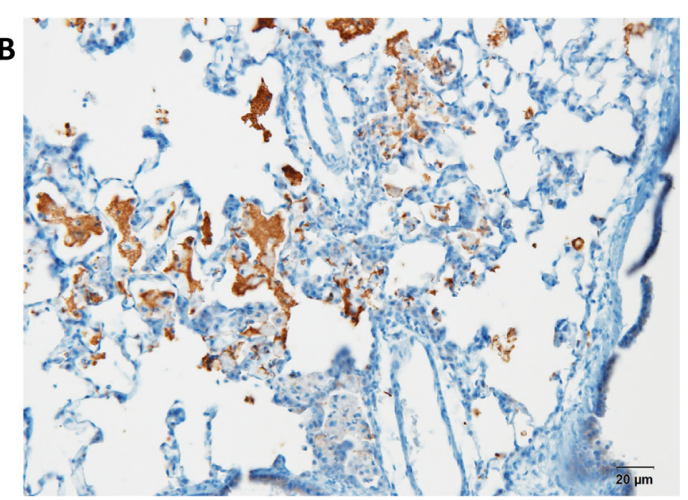

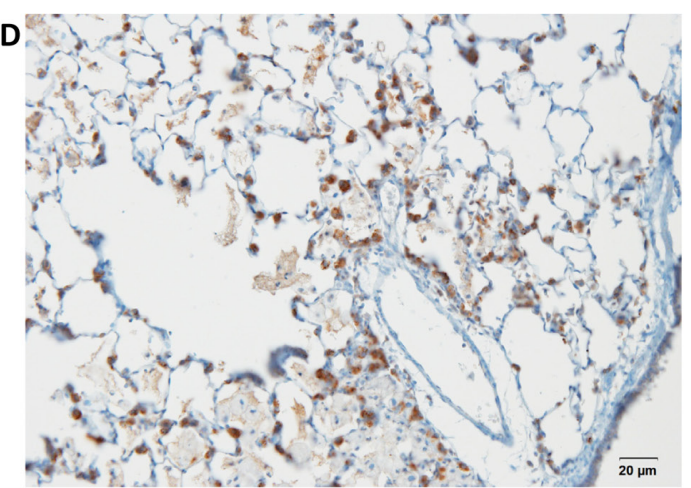

Fig. 2. Histopathological and immunohistochemical findings in quartz-induced inflammatory lesions in F344 rat lungs $(\times 200)$. A, H \& E; B, SP-A; C, SP-B; D, SP-C; and E, SP-D. The figure shows strongly positive staining in the alveolar mucus (B and E), alveolar and bronchial epithelial cells (C), and alveolar epithelial cells (D). 
The lesions were strongly positive for SP-A in the alveolar mucus (Fig. 2B), whereas they were weakly positive for SP-B in the mucus and strongly positive for SP-B in the alveolar and bronchial epithelial cells (Fig. 2C). In addition, they were weakly positive for SP-C in the mucus and strongly positive for SP-C in the alveolar epithelial cells (Fig. 2D). Moreover, they were strongly positive for SP-D in the mucus and partially positive for SP-D in the alveolar epithelial cells (Fig. 2E). The bronchiolar epithelial cells were strongly positive $(++)$ for SP-B and weakly positive $(+)$ for SP-A, SP$\mathrm{C}$, and SP-D. Furthermore, DHPN-induced proliferative lesions, hyperplasia, and adenomas in the lungs of F344 rats were weakly positive $(+)$ for SP-A (Fig. 3B), strongly $(++)$ positive for SP-B (Fig. 2C), strongly positive $(++)$ for SP-C
(Fig. 2D), and almost negative (-) for SP-D (Fig. 2E), although the normal alveolar epithelium was positive for SPD. For evaluation of the expression of the SPs, the histopathologically normal area of DHPN-treated lungs was used as a control. The results of the immunohistochemical analysis are summarized in Table 2. SP-B and SP-C were strongly expressed in the proliferative lesions, hyperplasias, and adenomas, whereas the expression of SP-A was weak and that of SP-D was lacking. However, SP-A and SP-D were strongly expressed in the mucus of the alveoli with inflammatory changes.

The expression levels of SP-A and SP-D were similar, with strong expression in the mucus of the alveoli with quartz-induced inflammatory lesions. SP-A and SP-D both
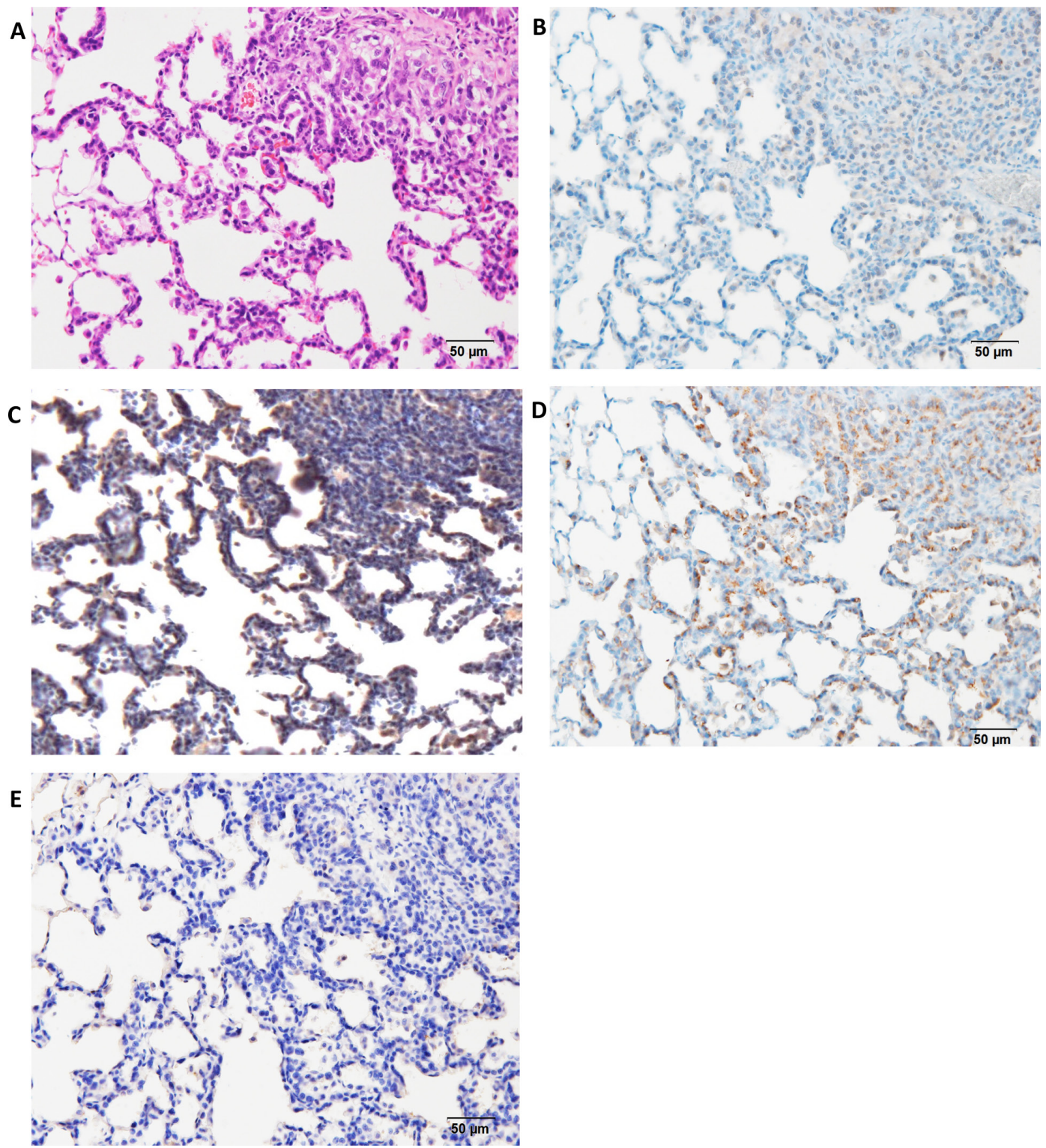

Fig. 3. Histopathological and immunohistochemical findings in DHPN-induced proliferative lesions, hyperplasias, and adenomas in $\mathrm{F} 344$ rat lungs ( $\times 200)$. A, H \& E; B, SP-A; C, SP-B; D, SP-C; and E, SP-D. The figure shows weak expression (+) of SP-A (B), strong $(++)$ expression of SP-B (C), strong expression (++) of SP-D (D), and almost no expression $(-)$ of SP-D (E). 
play significant roles in surfactant homeostasis and pulmonary immunity. Additionally, they are known to bind to various microbial pathogens that invade the lungs and label them for phagocytic clearance by the resident alveolar macrophages. They are also involved in the removal of apoptotic and necrotic cells and subsequent resolution of pulmonary inflammation ${ }^{28,29}$. The strong expression of SP-A and SP-D suggested the activation of macrophages to deal with the instilled quartz particles. It is noteworthy that the expression of SP-A was weak in the proliferative lesions because SP-A has been clinically used as a serous marker for human lung cancer in Japan. Some studies suggested that SP-A might have a role in the suppression of lung cancer progression, and SP-A expression by tumor cells leads to recruitment and activation of natural killer (NK) cells and tumor-associated macrophages ${ }^{30}$.

Moreover, SP-B was highly expressed in neoplastic lesions. The main function of SP-B is acceleration of the formation of a surface-active film composed of phospholipids at the air-water interface by increasing the adsorption rate ${ }^{31}, 32$. SP-B has anti-inflammatory activities, and it may be involved in protecting the lungs against oxidative stress $^{31,33,34}$. Moreover, circulating pro-SP-B was reported to be a potential biomarker for early detection of non-small cell-lung cancer (NSCLC) ${ }^{35}$. Pro-SP-B quickly undergoes proteolytic cleavage by cysteine proteases in the endoplasmic reticulum, resulting in the production and secretion of the 9-kD noncollagenous hydrophobic SP-B, which is the functional mature form ${ }^{36}$. Lung tumor cells, particularly adenocarcinoma, exhibit dysregulated SP-B synthesis, leading to overexpression of pro-SP-B with defective posttranslational modification of the precursor form into the mature hydrophobic form ${ }^{37,38}$.

SP-C, which is a specific marker of type II epithelial cells in the lungs ${ }^{39}$, showed strong expression in the proliferative lesions (Table 2). SP-B and SP-C possess physicochemical properties that reduce the surface tension of biological interfaces ${ }^{3}$. In a lung tumorigenesis model induced by a mixture of 4-(methyl-nitrosamino)-1-(3-pyridyl)-1-bu- tanone (NNK) and benzo[a]pyrene $(\mathrm{BaP})$ in $\mathrm{A} / \mathrm{J}$ mice, pulmonary SP-A, SP-B, and SP-C were expressed in the mouse lungs; however, only SP-C levels were higher in carcinogen-treated mice compared with the levels in the untreated mice ${ }^{40}$.

SPs are stored in lung type II epithelial cells. In the present study, the lung proliferative lesions, hyperplasias, and adenomas were also positive for SPs. These results suggested that lung hyperplasias and adenomas might originate from type II alveolar cells. SP-B and SP-C showed high expression in lung hyperplasias and adenomas, whereas the expression of SP-A and SP-D was strong in the mucus or exudates of inflammatory alveoli. These results suggested that SP-B and SP-C might be linked to lung tumorigenesis ${ }^{4}$.

\section{Potential Marker to Predict Lung Tumorigenesis}

Two types of bronchioloalveolar hyperplasia have been described in rodent lungs. The first type is inflammatory hyperplasia (i-hyperplasia) with a potential to recover in the future upon removal of the stimulating insult, and the other is latent tumorigenic hyperplasia (t-hyperplasia), which is an independent preneoplastic lesion for adenocarcinoma. In the present study, we focused on NNK-induced rat lung bronchioloalveolar hyperplasia, which decreases with time and reverts to normal, as well as DHPN-induced hyperplasia with tumorigenic potential to progress to adenoma and adenocarcinoma. Although NNK is a typical carcinogen used for induction of lung adenocarcinoma in female $\mathrm{A} / \mathrm{J}$ mice, the tumorigenic potential of $\mathrm{NNK}$ in rats is weaker than that in mice. In this study, differences between DHPNand NNK-induced hyperplasia were examined using immunohistochemical assays.

Lung samples with hyperplastic lesions were obtained from rats exposed to DHPN and fine particles (e.g., quartz), and 19 specific markers were examined to identify latent tumorigenic hyperplasia. In addition, to validate the most suitable marker of these 19 markers that might serve as a tumorigenic hyperplastic marker, additional experiments

Table 2. Ummary of the Expression of SP-A, SP-B, SP-C, and SP-D

\begin{tabular}{|c|c|c|c|c|}
\hline & SP-A & SP-B & SP-C & SP-D \\
\hline \multicolumn{5}{|c|}{ Typical characteristics from literature } \\
\hline Synthesis & Type II and Clara cells & Type II and Clara cells & Type II cell & Type II and Clara cells \\
\hline Innate immune defense & + & - & - & + \\
\hline \multicolumn{5}{|c|}{ Immunohistochemical findings from the present animal studies } \\
\hline \multicolumn{5}{|c|}{ Inflammatory lesions } \\
\hline Mucus in the alveoli & ++ & + & + & ++ \\
\hline Type II alveolar cells & - & ++ & ++ & + \\
\hline Macrophages & ++ & + & + & ++ \\
\hline \multicolumn{5}{|l|}{ Proliferative lesions } \\
\hline Hyperplasia & + & ++ & ++ & - \\
\hline Adenoma & + & ++ & ++ & - \\
\hline \multicolumn{5}{|l|}{ Control area } \\
\hline Type II alveolar cells & - & + & + & + \\
\hline Bronchiolar epithelial cells & + & ++ & + & - \\
\hline
\end{tabular}

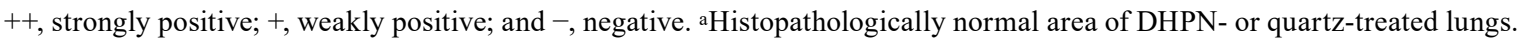


were performed in rats and mice ${ }^{41}$.

Formalin-fixed, paraffin-embedded (FFPE) lung samples with neoplastic lesions (hyperplasia, adenoma, and adenocarcinoma) or inflammatory lesions were obtained from our previous experiments. In one of the experiments ${ }^{27}$, male 6-week-old F344/DuCrlCrlj rats were treated with $0.1 \%$ DHPN in drinking water for 2 weeks or three ip injections of $10 \mathrm{mg}$ NNK suspended in $1 \mathrm{ml}$ of saline at weeks 0,1 , and 2 , and the were sacrificed at weeks 12 and 30. In another ${ }^{14}$, male 10-week-old F344/DuCrlCrj rats were exposed by IT instillation to fine particles of quartz, $\mathrm{CuO}$, or $\mathrm{NiO}$ at a dose of $2 \mathrm{mg} / \mathrm{rat}$ suspended in saline $(0.2 \mathrm{ml})$ on day 0 , and they were sacrificed on day 28 . In the lung samples with proliferative lesions, the marker antibodies examined were cyclin D1, napsin A, p27, thyroid transcription factor 1 (TTF-1), ki-67, cytokeratin (CK) 7, CK 20, CK 34ßE12, CK 5/6, SPA, p53, endothelial growth factor receptor (EGFR), estrogen receptor $\alpha(\mathrm{ER} \alpha)$, progesterone receptor (PR), carcinoembryonic antigen 1 (CEA), p16, proliferating cell nuclear antigen (PCNA), chromogranin A, and synaptophysin ${ }^{4}$. Macrophages and alveolar secretions in fine particle-induced inflammatory lesions and NNK-induced hyperplasias were positive for napsin A; however, its expression was lower in the alveolar walls (Fig. 4A and C). In contrast, DHPN-induced hyperplastic proliferative lesions showed strong posi- tive staining for napsin A in type II cells, which decreased with the increase in the malignant potential (Fig. 4B and D). The expression of napsin A in the walls of alveoli was stronger than that of TTF-1. Napsin A is an aspartic proteinase involved in the maturation of SP-B ${ }^{42}$. It is expressed in the cytoplasm of type II pneumocytes and Clara cells in the lungs, as well as the proximal tubular renal epithelium and exocrine cells of pancreas ${ }^{43,44}$.

To validate the possibility that napsin A might serve as a tumorigenic hyperplastic marker, further experiments were performed using rats and mice ${ }^{45}$. Various carcinogens were used to induce proliferative lesions, and immunohistochemical analysis of napsin $\mathrm{A}$ in the hyperplastic lung lesions was performed. In rats, the administered carcinogens were $0.1 \%$ DHPN in drinking water for 2 weeks, $1 \mathrm{~g} /$ $\mathrm{kg}$ urethane in saline ip 10 times every week, $30 \mathrm{mg} / \mathrm{kg}$ dimethylnitrosamine (DMN) in saline ip on day 0 , and $20 \mathrm{mg} /$ $\mathrm{kg} \mathrm{B}$ [a]P in saline IT using an aerosolizer. In mice, the used carcinogens were $2 \mathrm{mg} / \mathrm{mouse} \mathrm{NNK}, 5 \mathrm{mg} / \mathrm{mouse}$ urethane, and $1 \mathrm{mg} /$ mouse $\mathrm{B}[\mathrm{a}] \mathrm{P}$ administrated as a single ip injection.

Histopathological findings of rat and mouse lung lesions are summarized in Table 3 . In rats, only one hyperplastic lesion was detected at 16 weeks in the urethane-treated group, whereas only i-hyperplastic lesions were detected with unclear lesion borders and inflammatory cell induction
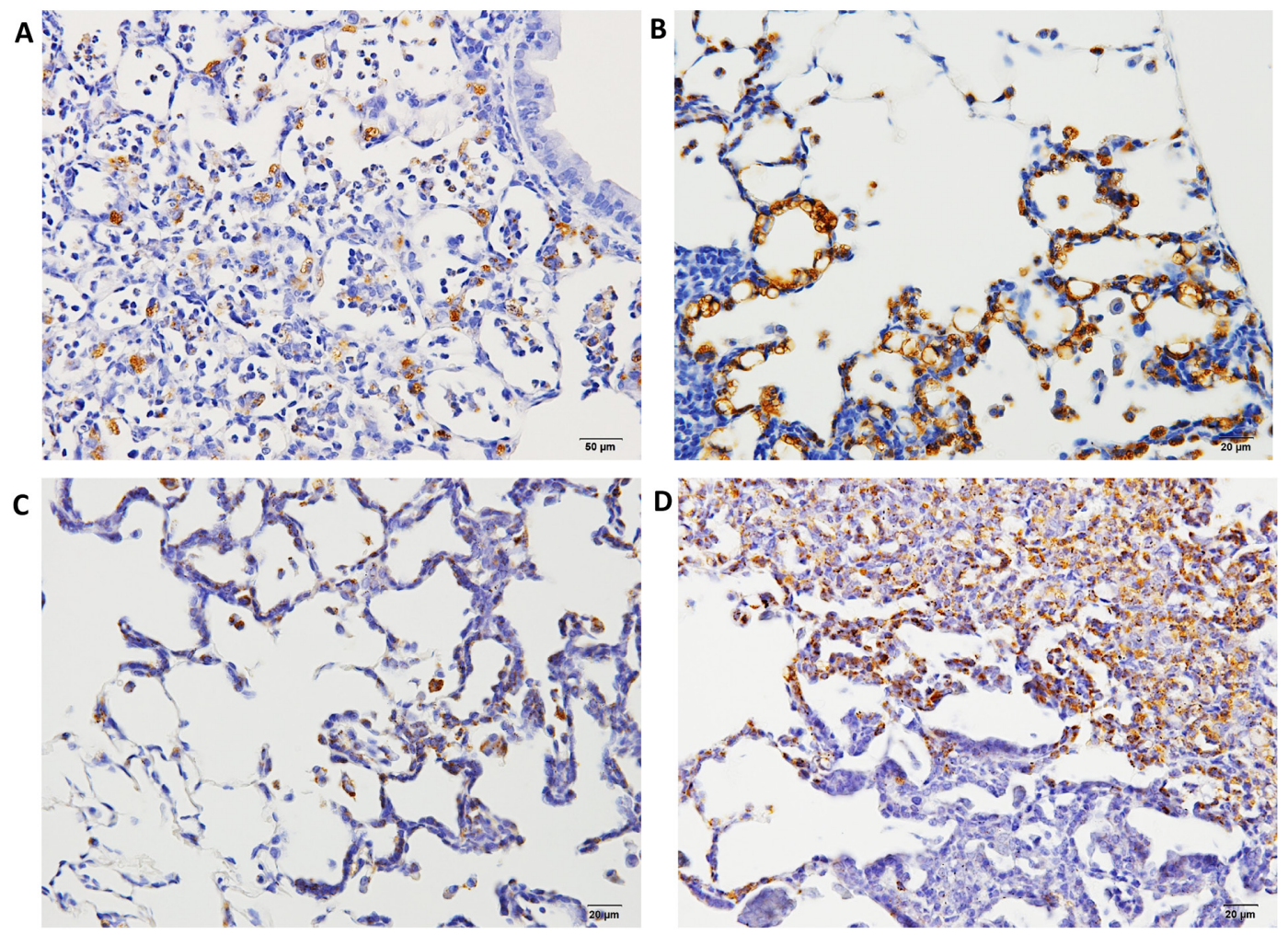

Fig. 4. Histopathological findings of Napsin A in hyperplasia or adenomas in F344 rat lungs. A, napsin A expression 12 weeks after treatment with NNK; B, napsin A expression 12 weeks after treatment with DHPN; C, napsin A expression 30 weeks after treatment with NNK and quartz; D, napsin A expression 30 weeks after treatment with DHPN. In proliferative lesions, including hyperplasias, the alveolar walls are strongly positive for napsin A (B and D), whereas in inflammatory lesions, the macrophages in the alveoli are positive for napsin A, although the alveolar walls of the alveoli are less stained (A and C). 
in the $\mathrm{B}[\mathrm{a}] \mathrm{P}$-treated group. DHPN-induced morphological t-hyperplasia was strongly positive $(++)$ for napsin A, whereas that induced by urethane and DMN was modestly positive $(+)$ for napsin $\mathrm{A}$ in the cytoplasm. B[a]P-induced morphological i-hyperplasia was equivocally positive $( \pm$ ), partial and weakly positive, for napsin A. Moreover, in DHPN- and DMN-induced morphological t-hyperplasia, napsin A expression was observed in the cytoplasm of the cells constituting the alveolar wall. Urethane-induced morphological t-hyperplasia exhibited a similar pattern, but it was equivocal. However, in B[a]P-induced morphological ihyperplasia, napsin A was weakly expressed by histiocytic macrophages. The other hyperplastic lesions in this group

Table 3. Histopathological Findings of Rat and Mouse Lung Lesions

\begin{tabular}{lcccc}
\hline Treatment & $\begin{array}{c}\text { Experimental } \\
\text { duration } \\
\text { (weeks) }\end{array}$ & Species & Effective no. $\begin{array}{c}\text { Napsin A in } \\
\text { hyperplasias }\end{array}$ \\
\hline DHPN & 32 & Rat & 5 & ++ \\
Urethane & 32 & Rat & 6 & + \\
DMN & 32 & Rat & 6 & + \\
B[a]P & 32 & Rat & 5 & +- \\
Urethane & 26 & Mouse & 5 & ++ \\
NNK & 26 & Mouse & 5 & + \\
B[a]P & 26 & Mouse & 5 & ++ \\
\hline
\end{tabular}

aExpression of napsin $\mathrm{A}$ in the alveolar wall in hyperplasias: ++, strongly positive; + , positive; $+/-$, equivocal; and - , negative. had similar staining properties regardless of the experimental period. In mice, morphological t-hyperplastic lesions induced by urethane and $\mathrm{B}[\mathrm{a}] \mathrm{P}$ were strongly positive $(++)$ for napsin A, and those induced by NNK were positive $(+$, diffused) for napsin A. The other carcinogenic hyperplastic lesions in all groups had similar staining properties.

Napsin A was shown to be a good marker for detection of hyperplastic lesions linked to actual neoplasia (t-hyperplasia $)^{41}$. Interestingly, clinical studies suggested that napsin A might be a highly specific marker for adenocarcinoma in the lungs 46,47 . However, to rule out lung metastasis from other organs (e.g., renal, thyroid, and endometrial carcinomas), implementation of other biologically specific markers should be considered ${ }^{46}$. In our experiment, the expression of SP-B did not completely correspond to that of napsin A.

Hyperplasia is defined as an increase in the number of cells in an organ or tissue, usually resulting in increased volume of this organ or tissue ${ }^{48}$. It could be physiological, which is usually reversible, or pathological, which varies in presentation from incidental to tumor-like lesions ${ }^{49}$. Alveolar wall thickening associated with inflammation was not attributable to the proliferation of type II alveolar cells but rather to the reaction of inflammatory cells or fibrosis; therefore, it was considered reversible hyperplasia (i-hyperplasia) (Fig. 5). This reversible hyperplasia was observed in the rat lungs after IT instillation of $\mathrm{ZnO}^{50}$. Our immunohistochemical analysis of napsin A showed an increase in the proliferation of lung alveolar cells. In the lungs, hyperplasia is

Normal alveolar epithelium

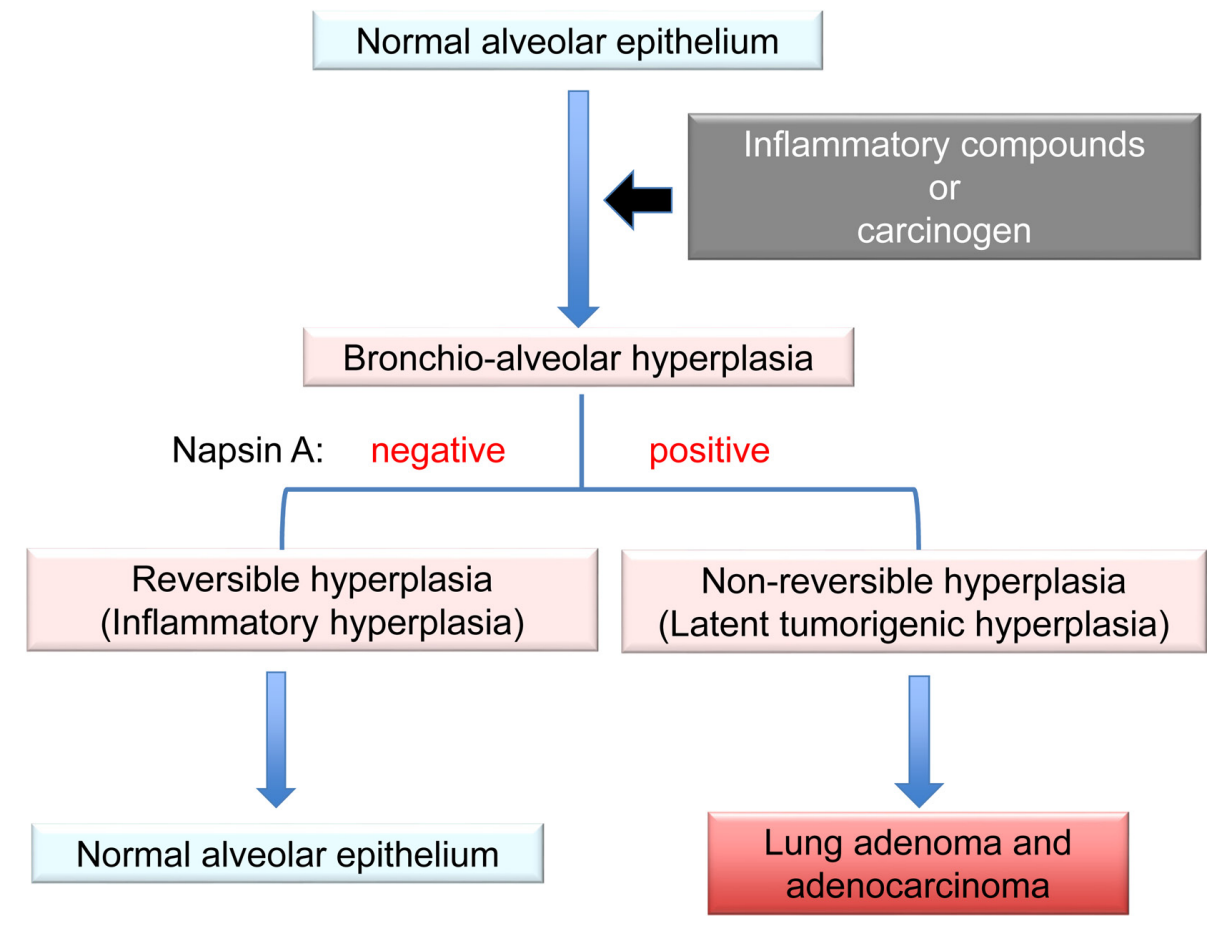

Fig. 5. Summary of features for discrimination of lung hyperplasias. Alveolar wall thickening because of inflammation is a reaction of inflammatory cells or fibrosis, called reversible hyperplasia. Bronchioloalveolar hyperplasia is characterized mainly by a focal increase in type II cells lining the interalveolar septa, called irreversible hyperplasia. Strong expression of napsin A in the alveolar walls in these hyperplastic lesions might suggest a tumorigenic potential with possible progression to adenoma and adenocarcinoma. 
characterized by a focal increase in type II cells lining the inter-alveolar septa ${ }^{51}$. This hyperplasia with proliferation of type II cells might be considered irreversible hyperplasia (t-hyperplasia). Thus, strong expression of napsin $\mathrm{A}$ in the alveolar walls could indicate subsequent progression to adenoma and adenocarcinoma. t-Hyperplasias induced by various carcinogens were positive for napsin $\mathrm{A}$, similar to the hyperplasias induced by DHPN in rats and mice. These lesions were strongly positive for napsin $\mathrm{A}$ in the alveolar walls. Therefore, it was concluded that napsin A might be a reliable and useful marker to determine the tumorigenic potential of lung hyperplasias in rodents ${ }^{45}$.

\section{Conclusions}

Ambroxol hydrochloride was shown to suppress quartz-induced lung inflammation via stimulation of pulmonary surfactant and airway serous secretion. Therefore, its administration might be recommended to prevent or minimize lung damage in individuals whose occupations involve exposure to dust containing quartz or other fine particles. SP-B and SP-C showed strong expression in lung hyperplasias and adenomas whereas the expression of SP-A and SP-D was strong in the mucus or exudates of inflammatory alveoli. These results suggested that SP-B and SP-C might be linked to lung tumorigenesis. Latent tumorigenic hyperplasias induced by various carcinogens were positive for napsin A, which is involved in the maturation of SP-B; this indicated a focal increase in type II pneumocytes in the lungs. Therefore, high expression of napsin $\mathrm{A}$ in the alveolar walls may serve as a useful marker for prediction of the tumorigenic potential of lung hyperplasias in rodents.

Ethics Approval and Consent To Participate: All animals in the experiments were maintained in the Division of Animal Experiments, Life Science Research Center, Kagawa University, according to the Institutional Regulations for Animal Experiments. The regulations included the best considerations on animal welfare and good practice of animal handling contributing to the replacement, refinement, and reduction of animal testing (3Rs).

Disclosure of Potential Conflicts of Interest: The authors declare that they have no potential conflicts of interest with respect to the research, authorship, and/or publication of this article.

Acknowledgments: Not applicable. This work was supported in part by Grants-in-Aid for Chemical Risk Research from the Ministry of Health, Labour and Welfare (MHLW) of Japan.

\section{References}

1. Pérez-Gil J, and Keough KM. Interfacial properties of surfactant proteins. Biochim Biophys Acta. 1408: 203-217.
1998. [Medline] [CrossRef]

2. Olmeda B, Umstead TM, Silveyra P, Pascual A, López-Barneo J, Phelps DS, Floros J, and Pérez-Gil J. Effect of hypoxia on lung gene expression and proteomic profile: insights into the pulmonary surfactant response. J Proteomics. 101: 179-191. 2014. [Medline] [CrossRef]

3. Perez-Gil J, and Weaver TE. Pulmonary surfactant pathophysiology: current models and open questions. Physiology (Bethesda). 25: 132-141. 2010. [Medline]

4. Yokohira M, Yamakawa K, Nakano Y, Numano T, Furukawa F, Kishi S, Ninomiya F, Kanie S, Hitotsumachi H, Saoo $\mathrm{K}$, and Imaida $\mathrm{K}$. Immunohistochemical characteristics of surfactant proteins a, B, C and d in inflammatory and tumorigenic lung lesions of f344 rats. J Toxicol Pathol. 27: 175-182. 2014. [Medline] [CrossRef]

5. Houtmeyers E, Gosselink R, Gayan-Ramirez G, and Decramer M. Effects of drugs on mucus clearance. Eur Respir J. 14: 452-467. 1999. [Medline] [CrossRef]

6. Nagahama F, Ito N, Momose T, Ogiwara M, Suetsugu S, Umeda $\mathrm{H}$, Kawai M, Maekawa N, Inaba N, Oda Y, Uchihira F, Konishiike J, Sera Y, Ooka Y, Oishi M, Nakajima S, Sewake N, Mochizuki K, Kodomari N, Inoue K, Tsurutani $\mathrm{H}$, and Nagano H. [Efficacy and safety of long-term treatment with mucolytic agent (NA872) in chronic respiratory disease patients]. Yakuri To Chiryo. 9: 2091-2104. 1981. (in Japanese)

7. Casals $\mathrm{C}$, and Cañadas $\mathrm{O}$. Role of lipid ordered/disordered phase coexistence in pulmonary surfactant function. Biochim Biophys Acta. 1818: 2550-2562. 2012. [Medline] [CrossRef]

8. Wright JR. Immunoregulatory functions of surfactant proteins. Nat Rev Immunol. 5: 58-68. 2005. [Medline] [CrossRef]

9. Minutti CM, García-Fojeda B, Sáenz A, de Las Casas-Engel M, Guillamat-Prats R, de Lorenzo A, Serrano-Mollar A, Corbí AL, and Casals C. Surfactant protein A prevents IFN-gamma/IFN-gamma receptor interaction and attenuates classical activation of human alveolar macrophages. J Immunol. 197: 590-598. 2016. [Medline] [CrossRef]

10. Gao X, Huang Y, Han Y, Bai CX, and Wang G. The protective effects of Ambroxol in Pseudomonas aeruginosa-induced pneumonia in rats. Arch Med Sci. 7: 405-413. 2011. [Medline] [CrossRef]

11. Zhi QM, Yang LT, and Sun HC. Protective effect of ambroxol against paraquat-induced pulmonary fibrosis in rats. Intern Med. 50: 1879-1887. 2011. [Medline] [CrossRef]

12. Yokohira M, Takeuchi H, Yamakawa K, Saoo K, Matsuda Y, Zeng Y, Hosokawa K, and Imaida K. Bioassay by intratracheal instillation for detection of lung toxicity due to fine particles in F344 male rats. Exp Toxicol Pathol. 58: 211-221. 2007. [Medline] [CrossRef]

13. Yokohira M, Kuno T, Yamakawa K, Hashimoto N, Ninomiya F, Suzuki S, Saoo K, and Imaida K. An intratracheal instillation bioassay system for detection of lung toxicity due to fine particles in f344 rats. J Toxicol Pathol. 22: 1-10. 2009. [Medline] [CrossRef]

14. Yokohira M, Kuno T, Yamakawa K, Hosokawa K, Matsuda Y, Hashimoto N, Suzuki S, Saoo K, and Imaida K. Lung toxicity of 16 fine particles on intratracheal instillation in a bioassay model using f344 male rats. Toxicol Pathol. 36: 620-631. 2008. [Medline] [CrossRef]

15. Tjoe-Nij E, de Meer G, Smit J, and Heederik D. Lung func- 
tion decrease in relation to pneumoconiosis and exposure to quartz-containing dust in construction workers. Am J Ind Med. 43: 574-583. 2003. [Medline] [CrossRef]

16. Repine JE, Bast A, Lankhorst I. Oxidative Stress Study Group Oxidative stress in chronic obstructive pulmonary disease. Am J Respir Crit Care Med. 156: 341-357. 1997. [Medline] [CrossRef]

17. Linden M, Rasmussen JB, Piitulainen E, Tunek A, Larson $\mathrm{M}$, Tegner H, Venge P, Laitinen LA, and Brattsand R. Airway inflammation in smokers with nonobstructive and obstructive chronic bronchitis. Am Rev Respir Dis. 148: 1226-1232. 1993. [Medline] [CrossRef]

18. Benson SC, Belton JC, and Scheve LG. Regulation of lung fibroblast proliferation and protein synthesis by bronchiolar lavage in experimental silicosis. Environ Res. 41: 61-78. 1986. [Medline] [CrossRef]

19. Yokohira M, Takeuchi H, Yamakawa K, Sao K, Ikeda M, Matsuda Y, Zeng Y, Hosokawa K, Maeta H, and Imaida K. Establishment of a bioassay system for detection of lung toxicity due to fine particle instillation: sequential histopathological changes with acute and subacute lung damage due to intratracheal instillation of quartz in F344 male rats. J Toxicol Pathol. 18: 13-18. 2005. [CrossRef]

20. van Berlo D, Knaapen AM, van Schooten FJ, Schins RP, and Albrecht C. NF-kappaB dependent and independent mechanisms of quartz-induced proinflammatory activation of lung epithelial cells. Part Fibre Toxicol. 7: 13. 2010. [Medline] [CrossRef]

21. Lawrence T. The nuclear factor NF-kappaB pathway in inflammation. Cold Spring Harb Perspect Biol. 1: a001651. 2009. [Medline] [CrossRef]

22. Jang YY, Song JH, Shin YK, Han ES, and Lee CS. Depressant effects of ambroxol and erdosteine on cytokine synthesis, granule enzyme release, and free radical production in rat alveolar macrophages activated by lipopolysaccharide. Pharmacol Toxicol. 92: 173-179. 2003. [Medline] [CrossRef]

23. Nagaoka S, and Kase Y. [Research for pharmacological effects of Ambroxol (NA872)]. Yakuri To Chiryo. 9: 18451854. 1981. (in Japanese)

24. Kanie S, Yokohira M, Yamakawa K, Nakano-Narusawa Y, Yoshida S, Hashimoto N, and Imaida K. Suppressive effects of the expectorant drug ambroxol hydrochloride on quartzinduced lung inflammation in F344 rats. J Toxicol Pathol. 30: 153-159. 2017. [Medline] [CrossRef]

25. Whitsett JA, and Weaver TE. Hydrophobic surfactant proteins in lung function and disease. N Engl J Med. 347: 21412148. 2002. [Medline] [CrossRef]

26. Hasegawa Y, Takahashi M, Ariki S, Saito A, Uehara Y, Takamiya R, Kuronuma K, Chiba H, Sakuma Y, Takahashi $\mathrm{H}$, and Kuroki Y. Surfactant protein A down-regulates epidermal growth factor receptor by mechanisms different from those of surfactant protein D. J Biol Chem. 292: 18565-18576. 2017. [Medline] [CrossRef]

27. Yokohira M, Hashimoto N, Yamakawa K, Suzuki S, Saoo $\mathrm{K}$, Kuno T, and Imaida K. Lung carcinogenic bioassay of $\mathrm{CuO}$ and $\mathrm{TiO}(2)$ nanoparticles with intratracheal instillation using F344 male rats. J Toxicol Pathol. 22: 71-78. 2009. [Medline] [CrossRef]

28. Moliva JI, Rajaram MV, Sidiki S, Sasindran SJ, Guirado E, Pan XJ, Wang SH, Ross P Jr, Lafuse WP, Schlesinger LS, Turner J, and Torrelles JB. Molecular composition of the al- veolar lining fluid in the aging lung. Age (Dordr). 36: 9633. 2014. [Medline] [CrossRef]

29. Jakel A, Qaseem AS, Kishore U, and Sim RB. Ligands and receptors of lung surfactant proteins SP-A and SP-D. Front Biosci (Landmark Ed). 18: 1129-1140. 2013. [Medline] [CrossRef]

30. Mitsuhashi A, Goto H, Kuramoto T, Tabata S, Yukishige S, Abe S, Hanibuchi M, Kakiuchi S, Saijo A, Aono Y, Uehara H, Yano S, Ledford JG, Sone S, and Nishioka Y. Surfactant protein A suppresses lung cancer progression by regulating the polarization of tumor-associated macrophages. Am J Pathol. 182: 1843-1853. 2013. [Medline] [CrossRef]

31. Um SJ, Lam S, Coxson H, Man SF, and Sin DD. Budesonide/ formoterol enhances the expression of pro Surfactant Protein-B in lungs of COPD patients. PLoS One. 8: e83881. 2013. [Medline] [CrossRef]

32. Whitsett JA, Ohning BL, Ross G, Meuth J, Weaver T, Holm BA, Shapiro DL, and Notter RH. Hydrophobic surfactantassociated protein in whole lung surfactant and its importance for biophysical activity in lung surfactant extracts used for replacement therapy. Pediatr Res. 20: 460-467. 1986. [Medline] [CrossRef]

33. Tokieda K, Ikegami M, Wert SE, Baatz JE, Zou Y, and Whitsett JA. Surfactant protein B corrects oxygen-induced pulmonary dysfunction in heterozygous surfactant protein B-deficient mice. Pediatr Res. 46: 708-714. 1999. [Medline] [CrossRef]

34. Miles PR, Bowman L, Rao KM, Baatz JE, and Huffman L. Pulmonary surfactant inhibits LPS-induced nitric oxide production by alveolar macrophages. Am J Physiol. 276: L186-L196. 1999. [Medline]

35. Sin DD, Tammemagi CM, Lam S, Barnett MJ, Duan X, Tam A, Auman H, Feng Z, Goodman GE, Hanash S, and Taguchi A. Pro-surfactant protein B as a biomarker for lung cancer prediction. J Clin Oncol. 31: 4536-4543. 2013. [Medline] [CrossRef]

36. Guttentag S, Robinson L, Zhang P, Brasch F, Bühling F, and Beers M. Cysteine protease activity is required for surfactant protein B processing and lamellar body genesis. Am J Respir Cell Mol Biol. 28: 69-79. 2003. [Medline] [CrossRef]

37. Khoor A, Whitsett JA, Stahlman MT, Olson SJ, and Cagle PT. Utility of surfactant protein B precursor and thyroid transcription factor 1 in differentiating adenocarcinoma of the lung from malignant mesothelioma. Hum Pathol. 30: 695-700. 1999. [Medline] [CrossRef]

38. O'Reilly MA, Gazdar AF, Clark JC, Pilot-Matias TJ, Wert SE, Hull WM, and Whitsett JA. Glucocorticoids regulate surfactant protein synthesis in a pulmonary adenocarcinoma cell line. Am J Physiol. 257: L385-L392. 1989. [Medline]

39. Archer F, Jacquier E, Lyon M, Chastang J, Cottin V, Mornex JF, and Leroux C. Alveolar type II cells isolated from pulmonary adenocarcinoma: a model for JSRV expression in vitro. Am J Respir Cell Mol Biol. 36: 534-540. 2007. [Medline] [CrossRef]

40. Kassie F, Anderson LB, Scherber R, Yu N, Lahti D, Upadhyaya $\mathrm{P}$, and Hecht SS. Indole-3-carbinol inhibits 4-(methylnitrosamino)-1-(3-pyridyl)-1-butanone plus benzo(a)pyrene-induced lung tumorigenesis in $\mathrm{A} / \mathrm{J}$ mice and modulates carcinogen-induced alterations in protein levels. Cancer Res. 67: 6502-6511. 2007. [Medline] [Cross- 
Ref]

41. Yokohira M, Kishi S, Yamakawa K, Nakano Y, Ninomiya F, Kinouch S, Tanizawa J, Saoo K, and Imaida K. Napsin A is possibly useful marker to predict the tumorigenic potential of lung bronchiolo-alveolar hyperplasia in F344 rats. Exp Toxicol Pathol. 66: 117-123. 2014. [Medline] [CrossRef]

42. Beljan Perak R, Durdov MG, Capkun V, Ivcevic V, Pavlovic A, Soljic V, and Peric M. IMP3 can predict aggressive behaviour of lung adenocarcinoma. Diagn Pathol. 7: 165. 2012. [Medline] [CrossRef]

43. Bishop JA, Sharma R, and Illei PB. Napsin A and thyroid transcription factor-1 expression in carcinomas of the lung, breast, pancreas, colon, kidney, thyroid, and malignant mesothelioma. Hum Pathol. 41: 20-25. 2010. [Medline] [CrossRef]

44. Stoll LM, Johnson MW, Gabrielson E, Askin F, Clark DP, and Li QK. The utility of napsin-A in the identification of primary and metastatic lung adenocarcinoma among cytologically poorly differentiated carcinomas. Cancer Cytopathol. 118: 441-449. 2010. [Medline] [CrossRef]

45. Yokohira M, Nakano-Narusawa Y, Yamakawa K, Hashimoto N, Yoshida S, Kanie S, and Imaida K. Validating the use of napsin A as a marker for identifying tumorigenic potential of lung bronchiolo-alveolar hyperplasia in rodents. Exp Toxicol Pathol. 69: 637-642. 2017. [Medline] [CrossRef]
46. Kadivar M, and Boozari B. Applications and limitations of immunohistochemical expression of "Napsin-A" in distinguishing lung adenocarcinoma from adenocarcinomas of other organs. Appl Immunohistochem Mol Morphol. 21: 191-195. 2013. [Medline]

47. Masai K, Tsuta K, Kawago M, Tatsumori T, Kinno T, Taniyama T, Yoshida A, Asamura H, and Tsuda H. Expression of squamous cell carcinoma markers and adenocarcinoma markers in primary pulmonary neuroendocrine carcinomas. Appl Immunohistochem Mol Morphol. 21: 292-297. 2013. [Medline] [CrossRef]

48. Kumar V, and Abbas A. Robbins and Cotran. Pathologic Basis of Disease. New York: Saunders. 6-7. 2004.

49. Al-Gahtany M, Horvath E, and Kovacs K. Pituitary hyperplasia. Hormones (Athens). 2: 149-158. 2003. [Medline] [CrossRef]

50. Xu J, Futakuchi M, Alexander DB, Fukamachi K, Numano T, Suzui M, Shimizu H, Omori T, Kanno J, Hirose A, and Tsuda H. Nanosized zinc oxide particles do not promote DHPN-induced lung carcinogenesis but cause reversible epithelial hyperplasia of terminal bronchioles. Arch Toxicol. 88: 65-75. 2014. [Medline] [CrossRef]

51. Gary AB, Scot LE, Michel RE, Charles AM, and William FM. Pathology of the Fischer Rat, Reference and Atlas. Academic Press, 350-357. 1990. 